\title{
MOBILE-BASED ONLINE EXAM APPLICATIONS USING PROBLEM WEIGHT CLASSIFICATION TECHNIQUES, GROUPING AND RANDOMIZING
}

\author{
Muhammad Iqbal'; Abdul Hamid²; Nuraeni Herlinawati ${ }^{3}$; Mochammad Abdul Azis; Muhammad \\ Rezki5; Ali Mustopa $^{6}$ \\ 1, 3, 4, 5, 6 Computer science \\ STMIK Nusa Mandiri, Jakarta, Indonesia \\ www.nusamandiri.ac.id \\ 1iqbal.mdq@nusamandiri.ac.id, ${ }^{3}$ nuraeni.nhw@nusamandiri.ac.id, ${ }^{4}$ mochammad.mmz@nusamandiri.ac.id \\ 5rezki.mdk@nusamandiri.ac.id,6alimustopa.aop@bsi.ac.id \\ 2Information Technology \\ Universitas Bina Sarana Informatika, Jakarta, Indonesia \\ www.bsi.ac.id \\ 2hamid.adh@bsi.ac.id
}

\begin{abstract}
Education is an agenda for designing the country's development. Implementation in the field of education is a joint responsibility of both the government and the community, educational institutions are one that plays an important role in the ongoing learning process activities one of which is the examination activities. The test is an evaluation of the learning process to obtain learning outcomes as a form of achievement recognition or completion in an educational unit. The test is still cheating, it is triggered by the lack of confidence in working on the exam questions and the same type of exam questions will provide an opportunity to chat and work together. The author aims to provide a solution in the form of the application of online-based online test applications using question weight classification techniques, grouping and randomization. This mobile-based online exam application was developed using the waterfall model. The results obtained from research on this mobile-based exam application has features to prevent screen capture or screenshots, prevent video recording or video recorder and prevent switching applications that can run multiplatform on Android and iOS. This application has been through the process of testing the user and distributing questionnaires to determine the feasibility of using the weight classification technique with a percentage of $80 \%$ so it is suitable for use in examination activities.
\end{abstract}

Keywords: Application, Online Test, Mobile, Classification, Question Weight.
Intisari-Pendidikan merupakan suatu agenda perancangan pembangunan negara. Pelaksanaan di bidang pendidikan menjadi tanggung jawab bersama baik pemerintah maupun masyarakat, lembaga pendidikan menjadi salah satu yang berperan penting terhadap berlangsungnya kegiatan proses belajar mengajar salah satunya yaitu kegiatan ujian. Ujian merupakan kegiatan evaluasi proses belajar untuk mendapatkan hasil belajar sebagai bentuk pengakuan prestasi atau penyelesaian dalam suatu satuan pendidikan. Pelaksanaan ujian masih mengalami tindakan kecurangan, hal tersebut dipicu kurangnya kepercayaan diri dalam mengerjakan soal ujian dan tipe soal ujian sama akan memberikan peluang untuk mencontek dan bekerja sama. Penulis bertujuan memberikan solusi berupa penerapan aplikasi ujian online berbasis online menggunakan teknik klasifikasi bobot soal, pengelompokan dan pengacakan. Aplikasi ujian online berbasis mobile ini dikembangkan dengan menggunakan model waterfall. Hasil yang didapatkan dari penelitian tentang aplikasi ujian berbasis mobile ini aplikasi tersebut mempunyai fitur untuk mencegah tangkap layar atau screenshot, mencegah rekam video atau video recorder dan mencegah pindah aplikasi yang dapat berjalan secara multiplatform di android dan iOS. Aplikasi ini telah melalui proses pengujian terhadap pengguna serta penyebaran kuesioner untuk mengetahui tingkat kelayakan penggunaan teknik klasifikasi bobot dengan hasil persentase 80\% sehingga layak untuk digunakan dalam kegiatan ujian.

Kata Kunci: aplikasi, ujian online, mobile, klasifikasi, bobot soal. 


\section{INTRODUCTION}

Education is a state development planning agenda that has the meaning to develop students' potential optimally in improving the lives of intelligent and cultured people (Hasmori, Sarju, Norihan, Hamzah, \& Sukr Saud, 2011). Meanwhile, implementation in the field of education becomes a joint responsibility of both the government and the community. Educational institutions play an important role in the continuing development of the potential of students because it is a place for ongoing learning and teaching activities. One of the potential developments in teaching and learning activities is examinations. Exams are activities evaluating the learning process that aims to measure the potential and test the quality of intelligence or learning outcomes of students as a form of recognition of learning achievement and completion in an educational unit. Problems that occur in conventional test implementation activities that require a very large cost in preparing the examination process and its vulnerability to fraud such as giving exam questions and cheating answers from other students (Nasution, 2013).

From conventional exam problems, some researchers have conducted web-based online exam research. The online test is a test or evaluation that is done through the internet (Kurniawan, Andrian, \& Ertina, 2014). Online exams are an integrated system to provide exams more quickly and effectively (Saraswati \& Putra, 2015). Examination still experiences cheating due to conventional and computerized exams, this is triggered by the lack of confidence of students in working on exam questions so that they trust other participants more, the same type of exam questions will allow students to cheat and work together (Arizqia \& Widodo, 2017). From these problems the authors are interested in making articles about mobile-based online exam applications using question weight classification techniques, grouping and randomization to help teach in terms of supervision to reduce cheating by students during the exam.

Based on the background above, the author aims to provide solutions in the form of the application of online-based online test applications using weight classification techniques of questions, grouping, and randomization. Classification of question weight is divided into 3 levels, namely easy, moderate and difficult. With this application, it is expected to increase intelligence, confidence, honesty and learning achievement to students effectively.

\section{MATERIAL AND METHODS}

In facilitating this research, the author uses several data collection methods as follows:

1. Observation Method

The author conducted the observation method at one of the Bina Sarana Informatics University, namely the Information Technology Faculty at the Information Systems Study Program at the Bina Sarana Informatika University, Pontianak City Campus.

\section{Interview Method}

Interviews were conducted to collect and obtain some information about the discussion of mobile-based online exam applications using question weight classification techniques, grouping and randomization by the question and answer with one of the lecturers at the University of Bina Sarana Informatika Pontianak City Campus to Mr. Agung Sasongko, M. Kom.

\section{Library Study}

A literature study is used as a support to obtain information by finding references sourced from books and journals related to online examinations.

The model used in this study is the waterfall model. The waterfall model is a model that provides a sequential software life-flow approach starting from analysis, design, coding, testing, and support (Rosa and Saladin, 2013). The stages of the waterfall model are as follows:

1. System Requirements Analysis

The author analyzes the system requirements and determines the design of the application to be built for user needs.

2. Design

At this stage, the authors do software architecture design using UML (Unified Modeling Language) to describe the flow of activity of the system. UML is a visual modeling method used in designing object-oriented software (M Teguh Prihandoyo, 2018).

\section{Coding}

In the next step, the writer does the coding process to create features to prevent screen capture or screenshots, to prevent video recording or video recorder and to prevent switching applications by using the mobile flutter framework.

\section{Implementation and Testing}

At the last stage the authors tested the mobile application using a smartphone device against the online test application to find out if the system was made to run well which aims to minimize errors. 


\section{RESULTS AND DISCUSSION}

1. System Requirements Analysis

In this mobile-based online exam application, there is one user who can interact in a system environment, namely students who are test-takers. The following is a specification of the requirements for things a student user can do, as follows:

1) Students log in.

2) Students can see yesterday's exam schedule.

3) Students can see the schedule for upcoming exams.

4) Students can work on the exam questions according to the predetermined exam schedule.

5) Students can see a history of exam results.

6) Students can see detailed data.

\section{Design}

The author uses UML (Unified Modeling Language) for system design on a mobile-based online exam application using question weight classification, grouping, and randomization techniques.

\section{a. Use Case Diagram}

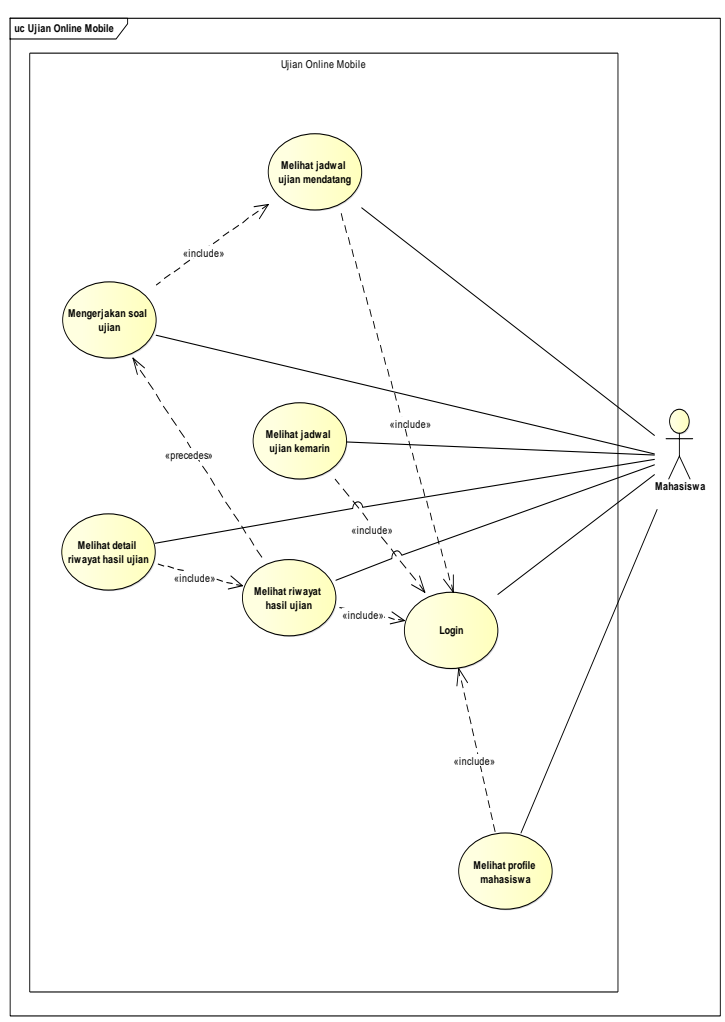

Sources: (Iqbal et al., 2020)

Figure 1 Use Case Diagram of an online exam Figure 1 is a use case diagram design that illustrates the expected functionality of the system. Use case diagrams are modeling to illustrate the behavior of the system.

\section{b. Activity Diagram}

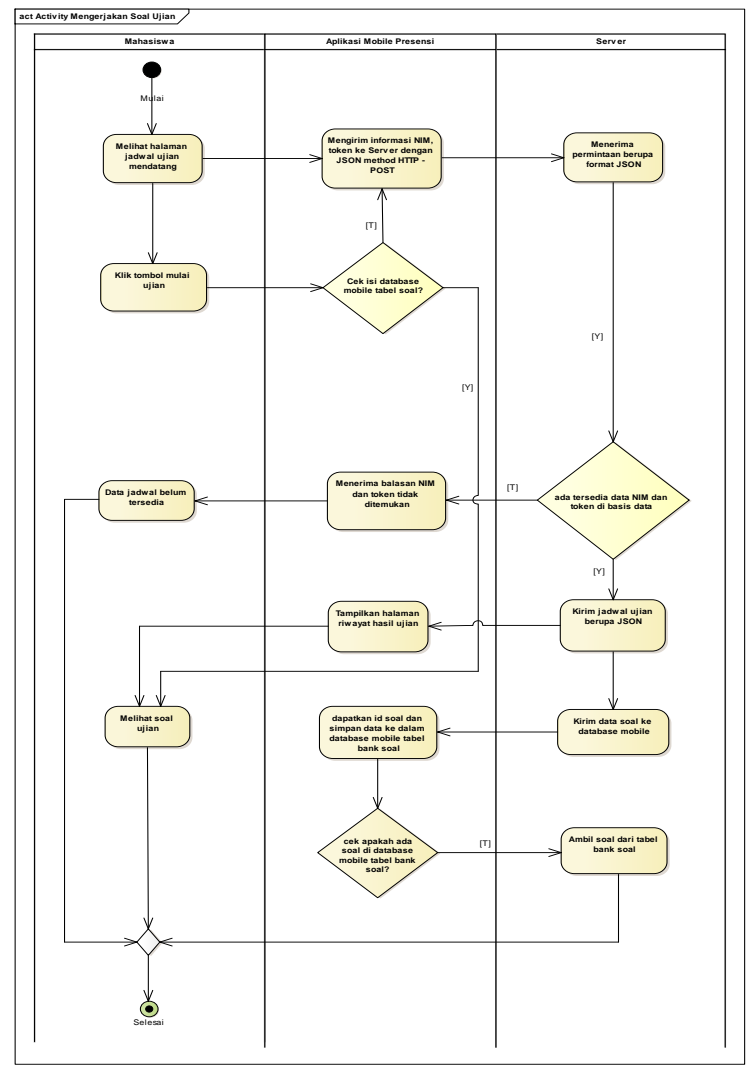

Sources: (Iqbal et al., 2020)

Figure 2. Activity Diagram working on exam questions

Figure 2 is an activity flowchart design activity doing exam questions. Activity Diagram is a description of the main activities of user activities on the system (Irmayani \& Susyatih, 2017).

\section{c. Class Diagram}

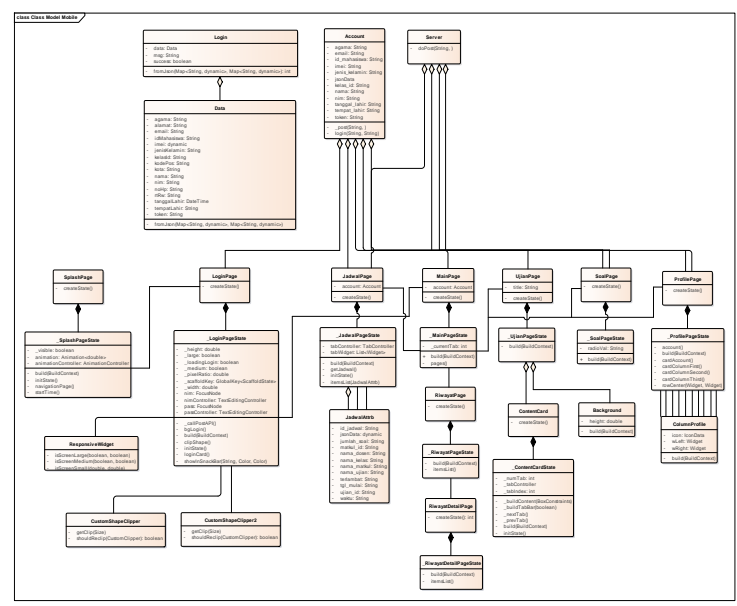

Sources: (Iqbal et al., 2020)

Figure 3 Class diagram of the online exam Figure 3 is a class design program flowchart showing the relationships between classes. Class Diagram is a description of the structure of application-oriented objects in terms of defining classes (Lisnawanty, 2014). 


\section{d. Deployment Diagram}

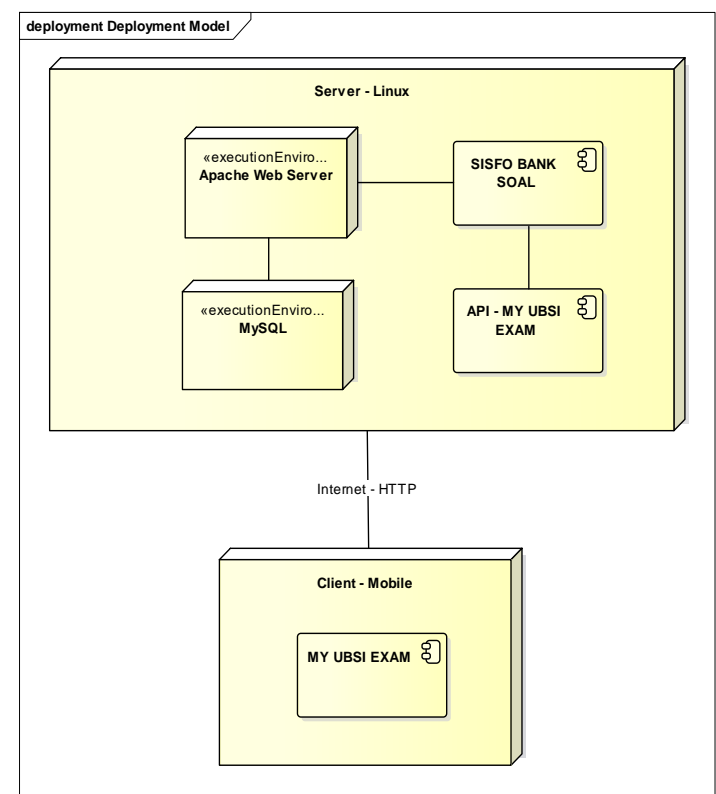

Sources: (Iqbal et al., 2020)

Figure 4. Deployment Diagram of an online exam

Figure 4 is a design deployment diagram that illustrates the relationship between hardware components and the process configuration in the system. Deployment diagrams are a description of the relationship between hardware and software and the output produced by the system (Irmayani \& Susyatih, 2017).

\section{3. $\quad$ Coding}

At this stage the authors do the coding to make features prevent screen capture or screenshots, prevent video recording or video recorders and prevent switching applications by using the Dart programming language, objectivec, and java.

\section{Source Code Dart}

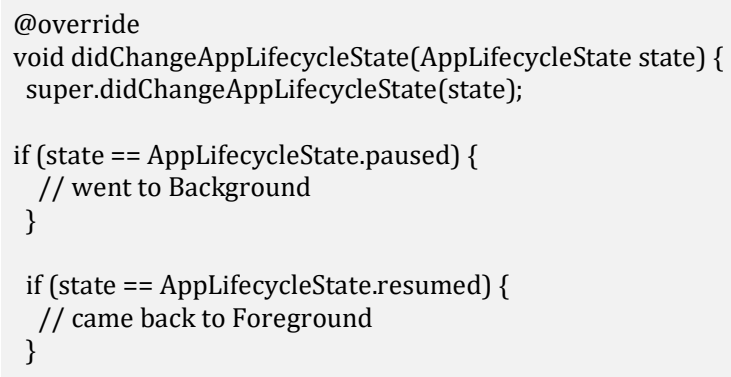

\section{Source Code Objective-C}

\#include "AppDelegate.h"

\#include "GeneratedPluginRegistrant.h"

@implementation AppDelegate

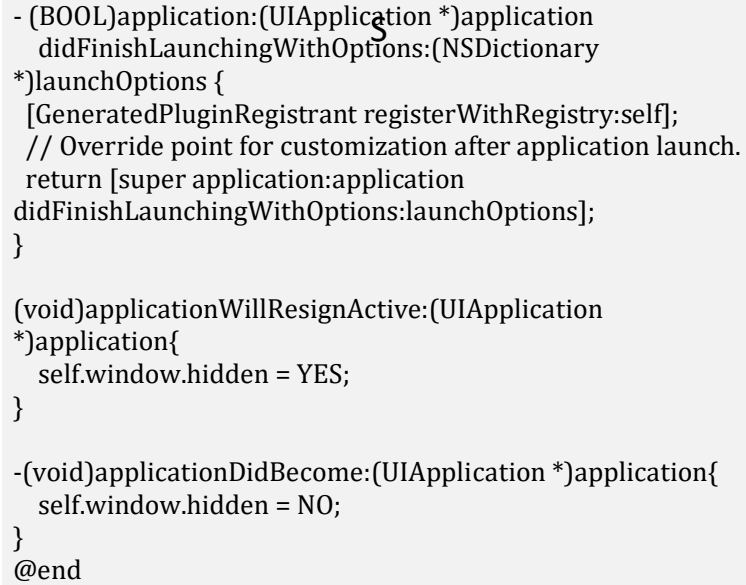

\section{Source Code Java}

package com.example.my_ubsi_exam;

import android.os.Bundle;

import io.flutter.app.FlutterActivity;

import io.flutter.plugins.GeneratedPluginRegistrant;

import android.view.WindowManager.LayoutParams;

public class MainActivity extends FlutterActivity \{

@Override

protected void onCreate(Bundle savedInstanceState) \{

super.onCreate(savedInstanceState);

GeneratedPluginRegistrant.registerWith(this); getWindow0.addFlags(LayoutParams.FLAG_SECURE); \}

\}

\section{Implementation and Testing}

a. Implementation

The author implements by making a mobile-based online test application using the mobile flutter framework with the Dart programming language. Following are the results of the implementation of the mobilebased online exam application as follows:

\section{1) Login Page}

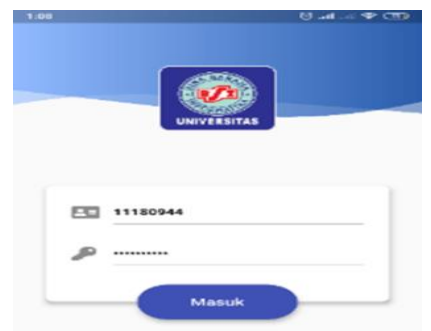

Sources: (Iqbal et al., 2020)

Figure 5. Login page

Figure 5 is the process login page to be able to access the exam activities in the mobile-based online exam application. 


\section{2) Exam Question Pages}

Sources: (Iqbal et al., 2020)

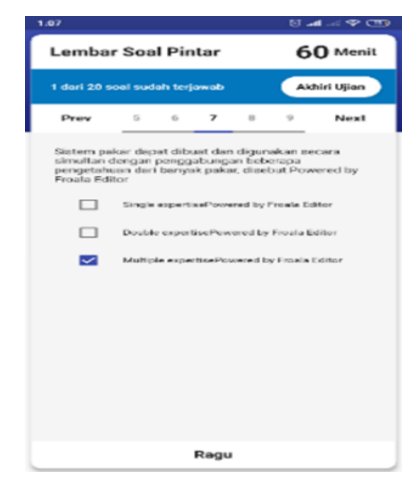

Figure 6. Exam Question Pages

Figure 6 is an exam question page for the exam activity process. The exam questions page has a feature telling the examinees that the questions have been answered. The system gives a green color to the question number box and the questions have been answered but doubt by pressing the doubt button, the system gives a yellow color in the question number box.

\section{3) Exam Results Page}

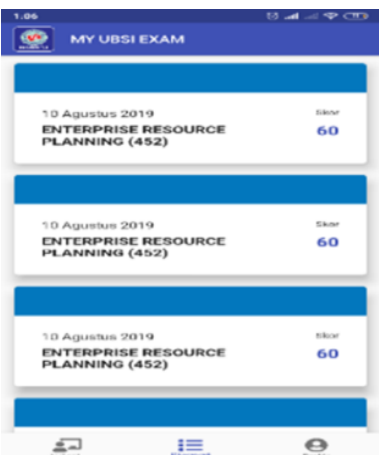

Sources: (Iqbal et al., 2020)

Figure 7. Exam Results Page

Figure 7 is an exam result page that displays eye information on the exam schedule, the lecture and exam score scores.

\section{b. Testing}

To find out how far this application can function properly and be useful for users, it is necessary to test the application of the user and the distribution of questionnaires to find out whether the use of weight classification techniques is good or not. The questionnaire questions will certainly obtain respondent's answer data regarding the use of question weight classification techniques, the collected data is then analyzed with quantitative descriptive techniques expressed in the form of a score distribution and percentage of the rating scale category that has been determined.
Table 1. Questionnaire Rating Scale

\begin{tabular}{lc}
\hline \multicolumn{1}{c}{ Answer } & Score \\
\hline $\begin{array}{l}\text { Strongly } \\
\text { Agree (SS) }\end{array}$ & 5 \\
\hline Agree (S) & 4 \\
\hline $\begin{array}{l}\text { Not Agree } \\
\text { (KS) }\end{array}$ & 3 \\
\hline Disagree (TS) & 2 \\
\hline $\begin{array}{l}\text { Strongly } \\
\text { Disagree } \\
\text { (STS) }\end{array}$ & 1 \\
\hline
\end{tabular}

Sources: (Iqbal et al., 2020)

The quantitative data obtained were then calculated using the McCall quality factor equation as follows:

Percentage of eligibility $(\%)=\frac{\text { Observed Score }}{\text { Expected Score }} 100$

After serving as a percentage, the next step is to describe and draw conclusions about each indicator in the feasibility aspects as in the table below.

Table 2. Feasibility Indicators

\begin{tabular}{ccc}
\hline No & Category & Score In Percentage \\
\hline 1 & Very Good & $81 \%-100 \%$ \\
\hline 2 & Good & $61 \%-80 \%$ \\
\hline 3 & Sufficient & $41 \%-60 \%$ \\
\hline 4 & Not Good & $21 \%-40 \%$ \\
\hline 5 & Very Poor & $0 \%-20 \%$ \\
\hline
\end{tabular}

Sources: (Iqbal et al., 2020)

Based on the questionnaire sheet that was distributed to 10 respondents, the answers obtained by respondents regarding the use of the weight classification of this problem. The following is a table 3 of recapitulation results of each respondent's answer to the use of the question weight classification.

Table 3. Recapitulation of Respondents' Answers

\begin{tabular}{|c|c|c|c|c|c|c|c|c|}
\hline \multirow{3}{*}{ No } & & \multicolumn{7}{|c|}{ Question } \\
\hline & & \multicolumn{2}{|c|}{ Display } & \multicolumn{3}{|c|}{ Material } & \multicolumn{2}{|c|}{ Easy Use } \\
\hline & & 1 & 2 & 3 & 4 & 5 & 6 & 7 \\
\hline 1 & Eri & 4 & 4 & 3 & 4 & 4 & 4 & 3 \\
\hline 2 & Ogi & 5 & 4 & 3 & 5 & 4 & 3 & 3 \\
\hline 3 & Sela & 4 & 4 & 4 & 5 & 4 & 3 & 3 \\
\hline 4 & Erna & 4 & 4 & 4 & 4 & 5 & 4 & 4 \\
\hline 5 & Wafia & 5 & 4 & 4 & 4 & 4 & 4 & 4 \\
\hline 6 & Ando & 5 & 4 & 4 & 5 & 4 & 4 & 4 \\
\hline 7 & Abdul & 4 & 4 & 4 & 5 & 4 & 4 & 4 \\
\hline 8 & Ali & 5 & 5 & 4 & 4 & 4 & 5 & 4 \\
\hline 9 & Sifa & 4 & 4 & 4 & 4 & 4 & 4 & 4 \\
\hline \multirow[t]{2}{*}{10} & Hamim & 4 & 4 & 3 & 4 & 4 & 4 & 3 \\
\hline & Total & 44 & 41 & 37 & 44 & 41 & 39 & 36 \\
\hline
\end{tabular}

Sources: (Iqbal et al., 2020)

From the table 3 recapitulation of respondents' answers, the results of the questionnaire answers will be obtained as a percentage. Table 4 below is the result of the 
calculation of the questionnaire answers for each question.

Table 4. Results of Calculation of Questionnaire Answers

\begin{tabular}{|c|c|c|c|c|}
\hline No & Criteria & Question & Score & $\begin{array}{c}\text { Percentage } \\
(\%)\end{array}$ \\
\hline 1 & \multirow[b]{2}{*}{$\begin{array}{c}\text { App } \\
\text { Display }\end{array}$} & $\begin{array}{l}\text { Application } \\
\text { The use of } \\
\text { weight } \\
\text { classification } \\
\text { techniques is } \\
\text { this problem } \\
\text { interesting? }\end{array}$ & 44 & 88 \\
\hline 2 & & $\begin{array}{l}\text { Does the } \\
\text { application } \\
\text { get } \\
\text { information } \\
\text { about the } \\
\text { differences } \\
\text { between each } \\
\text { type of } \\
\text { weight } \\
\text { classification? }\end{array}$ & 41 & 82 \\
\hline 3 & \multirow{3}{*}{$\begin{array}{l}\text { Material } \\
\text { Questions }\end{array}$} & $\begin{array}{l}\text { Question } \\
\text { Material } \\
\text { Question } \\
\text { material is } \\
\text { given } \\
\text { according to } \\
\text { need? }\end{array}$ & 37 & 74 \\
\hline 4 & & $\begin{array}{l}\text { The } \\
\text { information } \\
\text { provided by } \\
\text { this } \\
\text { application } \\
\text { already meets } \\
\text { the needs of } \\
\text { users? }\end{array}$ & 44 & 88 \\
\hline 5 & & $\begin{array}{l}\text { Model } \\
\text { delivery of } \\
\text { matter from } \\
\text { interesting } \\
\text { applications. }\end{array}$ & 41 & 82 \\
\hline 6 & \multirow{2}{*}{ Ease Use } & $\begin{array}{l}\text { Usage Any } \\
\text { features } \\
\text { contained in } \\
\text { this } \\
\text { application } \\
\text { run well? }\end{array}$ & 39 & 78 \\
\hline 7 & & $\begin{array}{l}\text { The functions } \\
\text { of the } \\
\text { application } \\
\text { buttons are } \\
\text { easy to } \\
\text { understand. }\end{array}$ & 36 & 72 \\
\hline & Tota & & 40 & 80 \\
\hline
\end{tabular}

Sources: (Iqbal et al., 2020)

From the results of a survey of user acceptance of the application using a questionnaire on 10 sample respondents, it was concluded that overall the use of this question weight classification technique has been assessed well by users with a percentage of $80 \%$ so that this application is eligible to be used in the examination process.
1) Unit Testing

In this unit test conducted on the user side as a student who is a user.

a) If the NIM and password are not filled in, a message will say "NIM or Blank Password".

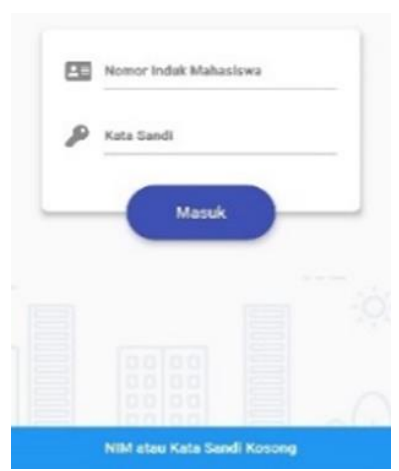

Sources: (Iqbal et al., 2020)

Figure 8. Testing of NIM Units and Blank Passwords

b) If the Password is not filled in, a message will say "NIM or Empty Password" will come out.

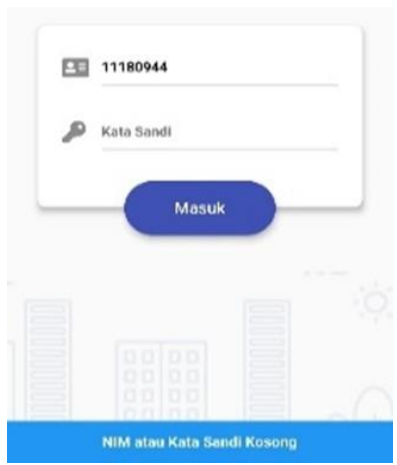

Sources: (Iqbal et al., 2020)

Figure 9. Testing of Empty Password Units

c) If the NIM or Password that is filled in is incorrect then there will be a message that reads "NIM or Incorrect Password".

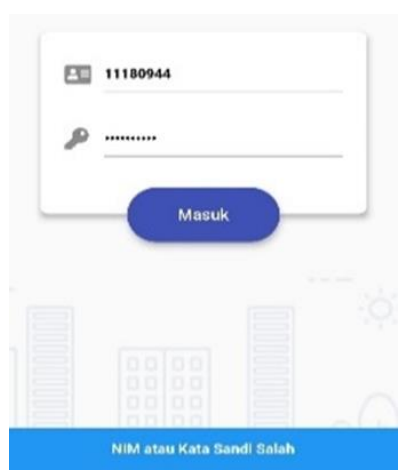

Sources: (Iqbal et al., 2020)

Figure 10. Testing for NIM Units or Incorrect Passwords 
2)

Integration Testing

Integration Testing is a test of systems or subsystems that make up integrated components. Admin Home Menu; Student Data Menu on Admin; Data Department Majors on Admin; Lecturer Data Menu at Admin; Course Data Menu in Admin; Menu Type Test Data on Admin; ClassLecturer Relationship Menu in Admin; Department-Subject Relations in the Admin Menu; Question Bank Menu on Admin; Menu Examination Schedule in the Admin; User Management Menu on Admin; The settings menu in Admin.

\section{3) System Testing}

System testing to ensure system functions are carried out correctly in the main facilities contained in the application: Schedule Menu; History Menu; Profile Menu.

\section{4) Acceptance Testing}

This test was tested on a Vivo V17 Pro smartphone with an Android OS.

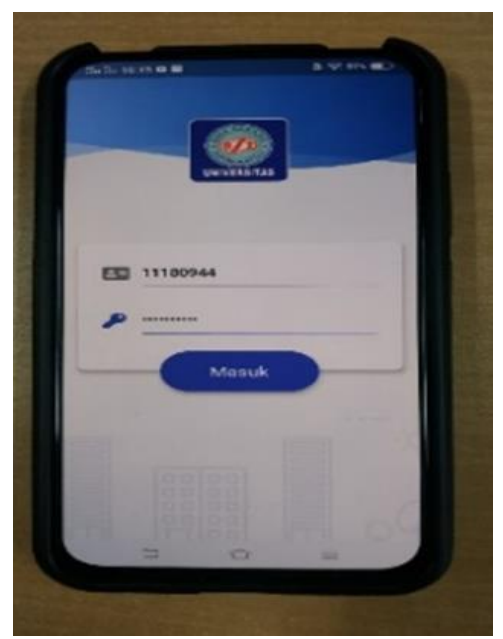

Sources: (Iqbal et al., 2020)

Figure 11 Display Login

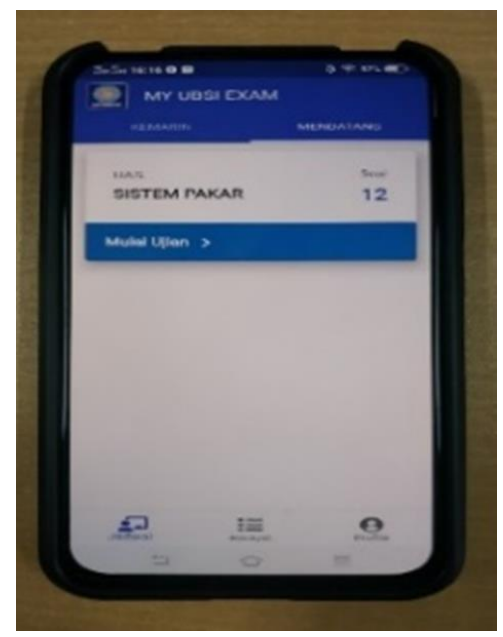

Sources: (Iqbal et al., 2020)

Figure 12 Displaying Future Test Schedules

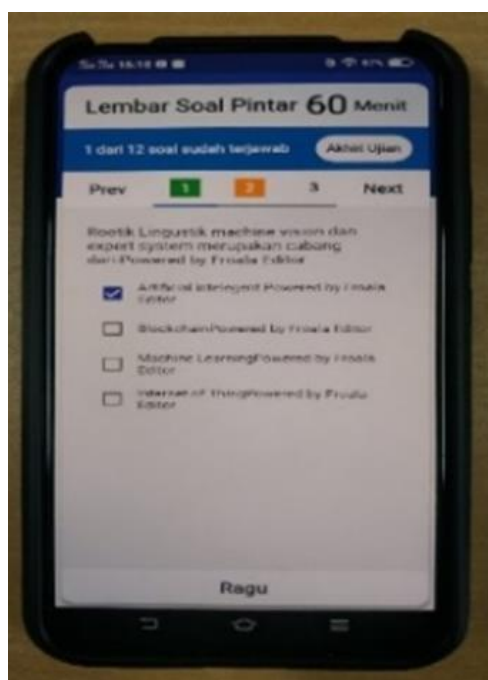

Sources: (Iqbal et al., 2020)

Figure 13 Exam Display

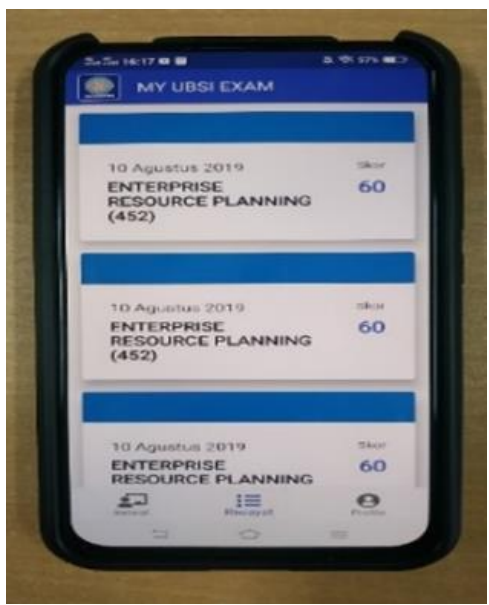

Sources: (Iqbal et al., 2020)

Figure 14 Display of Exam Results

\section{CONCLUSION}

This research has been successful by using a mobile-based online exam application using question weight classification, grouping, and randomization techniques that can run multiplatform namely Android and iOS. This application also provides features to prevent screen capture or screenshots, to prevent video recordings or video recorders and to prevent switching applications that aim to serve as lecturers' aids in supervising exam activities. Based on the survey results of user acceptance on the optimization level of the use of weight classification techniques, the conclusions of this study are: 1) Question No. 1 in this application has been rated very well, $88 \%$ of respondents felt the appearance of the online exam application is quite interesting. 2) For question no. 2, respondents also responded very well, as many as $82 \%$ of users agreed that this online exam 
application had a simple and attractive color to use. 3) For question 3 question material category getting a good response, as many as $74 \%$ of respondents felt the information provided by this online test application had fulfilled the user's needs. 4) While the question number 4 respondent responded very well, $88 \%$ of users felt the material about this matter helped the learning process. 5) For question no. 5 respondents gave very good responses, $82 \%$ of users found the model of delivering questions from the online exam application interesting. 6) In question no. 6 , the respondent gave a good response, as many as $78 \%$ of respondents considered that every feature contained in this online test application was running well so that it could help in the process of using the application. 7) As for question number 7 respondents responded well, as many as $72 \%$ of respondents felt the function of the buttons on the online exam application was easy to operate. Based on the results of respondents' answers from 7 questions in these three categories, it was concluded that overall this online exam application has been rated well by users with a percentage of $80 \%$ so that this application is eligible to be used in exam activities.

\section{REFERENCE}

Arizqia, M. G., \& Widodo, A. A. (2017). Rancang Bangun Aplikasi Dengan Linear Congruent Method (LCM) Sebagai Pengacakan Soal. JOINTECS Uournal of Information Technology and Computer Science), 2(1), 16.

https://doi.org/10.31328/jointecs.v2i1.412

Hasmori, A. A., Sarju, H., Norihan, I. S., Hamzah, R., \& Sukr Saud, M. (2011). Pendidikan , Kurikulum Dan Masyarakat: Satu Integrasi. Journal of Edupres.
Iqbal, M., Hamid, A., Herlinawati, N., Aziz, M. A., Rezki, M., \& Mustopa, A. (2020). APLIKASI UJIAN ONLINE BERBASIS MOBILE MENGGUNAKAN TEKNIK KLASIFIKASI BOBOT SOAL, PENGELOMPOKAN DAN PENGACAKAN (Vol. 17 No). Retrieved from https://ejournal.nusamandiri.ac.id/index.p hp/techno

Irmayani, W., \& Susyatih, E. (2017). Sistem Informasi Anggaran Pendapatan dan Belanja Desa Berorientasi Objek. Khatulistiwa Informatika, V(1), 58-63.

Kurniawan, D., Andrian, R., \& Ertina, L. (2014). Pengembangan Sistem Ujian Online Sekolah. Jurnal Komputasi, 2(2), 36-40.

Lisnawanty. (2014). Perancangan Sistem Informasi Kearsipan Surat Masuk Dan Surat Keluar Berbasis Multiuser. Jurnal Khatulistiwa Informatika, 2(2), 161-175. Retrieved from ejournal.bsi.ac.id/ejurnal/index.php/khatul istiwa/article/view/1639\%0A

M Teguh Prihandoyo. (2018). Unified Modeling Language (UML) Model Untuk Pengembangan Sistem Informasi Akademik Berbasis Web. Jurnal Informatika: Jurnal Pengembangan IT, 3(1), 126-129.

Nasution, S. D. (2013). Penerapan metode linier kongruendan algoritma vigenère chiper pada aplikasi sistem ujian berbasis lan. STMIK Budi Darma Medan.

Saraswati, N. W. S., \& Putra, D. M. D. U. (2015). Sistem Ujian Online Berbasis Website di STMIK STIKOM Indonesia. S@Cies. 